УДК 378. 046. -021. 68

DOI: $\underline{10.35619 / \text { iiu.v2i13.385 }}$

Петренко Оксана

доктор педагогічних наук, професор, завідувач кафедри теорії і методики виховання Рівненського державного гуманітарного університету, м. Рівне, Україна

ORCID: 0000-0001-6906-3542, e-mail: oksana.petrenko@rshu.edu.ua

Баліка Людмила кандидат педагогічних наук, доцент, доцент кафедри теорії і методики виховання Рівненського державного гуманітарного університету, м. Рівне, Україна

ORCID: 0000-0003-0042-7744 e-mail: liudmyla.balika@rshu.edu.ua

Бричок Світлана кандидат педагогічних наук, доцент, доцент кафедри педагогіки початкової освіти Рівненського державного гуманітарного університету, м. Рівне, Україна ORCID: 0000-0001-8508-8395, e-mail: brychok.zd@gmail.com

\title{
АСПІРАНТУРА В УКРАЇНІ ЯК ОСНОВНА ФОРМА ПІДГОТОВКИ НАУКОВИХ КАДРІВ: РЕФЛЕКСІЯ ТРИВАЛІСТЮ У СТОЛІТТЯ
}

Анотація. В статті здійснено рефлексивний аналіз діяльності аспірантури в Україні як основної форми підготовки наукових кадрів упродовж століття.

3'ясовано, що аспірантура в Україні на сьогодні Законами «Про освіту» (2017), «Про вищу освіту» (2014) нормативно визначена основною формою підготовки науково-педагогічних і наукових кадрів.

Досліджено внесок у підготовку аспірантів науково-дослідних кафедр педології; проаналізовано програми підготовки аспірантів на кафедрі в Київському інституті народної освіти. Схарактеризовано діяльність аспірантури з педагогіки в Українському Науково-Дослідчому Інституті Педагогіки (УНДІПі) в Харкові, розглянуто навчальні плани, основні засади їх функціонування.

Вивчено низку нормативних документів, які визначали діяльність аспірантури в українських закладах освіти, що регулювали підготовку наукових i науково-педагогічних кадрів через аспірантуру, як-то: «Положення про порядок підготовки науковців при вищих навчальних закладах і науково-дослідних установах» (1925); Постанова ЦВК СРСР

(C) Петренко О., Баліка Л., Бричок С., 2021 


\section{Інноватика у вихованні. Випуск 13.Том 2. 2021.}

«Про навчальні програми й режими у вищій школі й технікумах» (1932); Постанова «Про розмір стипендій для аспірантів втузів, вузів і науководослідних інститутів» (1933); Постанова «Про підготовку наукових і науково-педагогічних працівників» (1934); Закон України «Про заходи щодо поліпшення підготовки науково-педагогічних кадрів через аспірантуру» (1948); Постанова ВАК «Про підсумки роботи 3 атестації наукових кадрів за 1947/1948 навчальний рік» (1948); Положення про аспірантуру при вищих навчальних і науково-дослідних установах (1962); Постанова ЦК КПРС і Ради Міністрів СРСР «Про заходи щодо покращення підготовки й використання науково-педагогічних і наукових кадрів» (1987); Про затвердження Порядку підготовки здобувачів вищої освіти ступеня доктора філософії та доктора наук у закладах вищої освіти (наукових установах)» (2016).

Доведено, що у 30-х рp. модель аспірантури в СРСР була «освітньою»; у 50- х роках XX ст. розвиток аспірантури пішов шляхом скорочення освітньої підготовки й трансформувався в «дослідницьку» модель; на початку XXI ст. аспірантура реалізовує освітньо-дослідницьку модель підготовки здобувачів освіти.

Ключові слова: аспірантура, підготовка наукових кадрів, аспірант, доктор філософії, рефлексія.

Постановка проблеми. Нині в українській системі освіти актуальним $\epsilon$ питання реформування вітчизняної системи підготовки наукових $\mathrm{i}$ науково-педагогічних кадрів у цілому й такої важливої ії складової, як аспірантура. Реформування традиційно актуалізує вивчення історичного досвіду, позаяк його незнання чи ігнорування загрожує небезпекою ускладнення наявних у цій сфері проблем. У контексті цього, на наш погляд, має сенс здійснення рефлексії проблеми системи підготовки кадрів через аспірантуру у вітчизняній історії освіти й педагогіки.

Аналіз останніх досліджень із проблеми. Зміст підготовки наукових кадрів на основі вивчення науково-педагогічних праць i архівних матеріалів проаналізований Б. Лєбіним (1966), С. Кононовою (2005), Р. Ільницьким, Н. Процишиною (2016), А. Філатовою (2010) та ін.

Аналіз зазначених досліджень дає можливість стверджувати, що власне підготовка наукових працівників, аспірантів неодноразово були об'єктом вивчення, на відміну від форми їх підготовки - аспірантури.

Рефлексія діяльності аспірантури в Україні, особливо у 20-ті рр. XX ст., видається нам цікавою i досить інформативною, оскільки вимальовуються численні паралелі 3 сучасним етапом організації підготовки наукових кадрів.

Мета пропонованої розвідки - здійснення аналізу діяльності аспірантури в Україні як основної форми підготовки наукових кадрів, починаючи з 20-х рр. XX ст. і до сьогодні.

Виклад основного матеріалу дослідження. Аспірантура (від лат. aspiro, тут - прагну, aspirans (aspirantis) - той, хто до чогось прагне) в 


\section{Інноватика у вихованні. Випуск 13.Том 2. 2021.}

Україні на сьогодні Законами «Про освіту» (2017), «Про вищу освіту» (2014) нормативно визначена основною формою підготовки науковопедагогічних і наукових кадрів.

Датою виникнення аспірантури як системи підготовки кадрів вищої кваліфікації прийнято вважати 1925 р., позаяк офіційно інститут аспірантури був заснований «Інструкцією про порядок підготовки наукових працівників при науково-дослідних інститутах i вузах за прикладними, точними та природничими науками», затвердженою Народним комісаріатом освіти РСФСР (Наркомос) у червні 1925 p. (Справочник аспиранта. 1928). Дійсно, з цього року підготовка наукових кадрів стала більш чіткою, організованою і єдиною, хоча, насправді, власне процес підготовки аспірантів розпочався набагато раніше.

Після приходу до влади в жовтні 1917 р. більшовики почали вирішувати завдання «завоювання» науки й вищої школи: важливо було не лише залучити «стару» наукову інтелігенцію на свою сторону, але й створити марксистську науку, підготувати наукові кадри. Відтак, у жовтні 1918 p. Рада народних комісарів РСФСР прийняла декрет, яким скасовувались наукові ступені (доктора, магістра) і звання, визначені в дореволюційній Росії. В країні встановлювалося єдине звання професора для всіх осіб, які викладали, і звання викладача для інших працівників вищої школи.

Що стосується системи підготовки наукових кадрів, то спочатку вона майже не змінилась: як і до революції, підготовка вчених проходила у формі «залишення» на кафедрах за рекомендацією професорів здібних студентів, яких готували до наукової й педагогічної діяльності від двох до трьох років.

На початку 1920-х рр. в країні обговорювалось питання про те, чим i як можна замінити систему «залишення». Приміром, відомий вчений, академік, випускник Київського університету, працівник Наркомосу Отто Шмідт наполягав на реорганізації й розділенні масової підготовки фахівців і підготовки наукових працівників (Иванова,1980). Цікаво, що за твердженнями його сина - відомого історика Сігурда Шмідта, Отто Шмідт поняття «аспірант» вигадав просто в кабінеті Леніна, і з того моменту воно почало активно використовуватися у вітчизняній науці (Лескова, 2012). Втім, ніяких документальних підтверджень цьому факту допоки не знайдено, що залишає простір для наукового пошуку.

Необхідно зазначити, що в Українській республіці підготовка наукових працівників проводилась Інститутами народної освіти, науководослідними інститутами або науково-дослідними кафедрами ще з 1921 р. відповідно до таких нормативних документів: Постанови Раднаркому УСРР «Про утворення науково-дослідних кафедр та забезпечення науково-дослідних кафедр» (1921) (Вища школа УРСР за 50 років: в 2 ч., 1967), «Тимчасового положення про Вищі Навчальні заклади У.С.Р.Р.» (1922) (Временное положение о Высших Учебных заведениях У.С.С.Р., 1922). Задля подолання гострої нестачі кадрів вищої наукової кваліфікації 


\section{Інноватика у вихованні. Випуск 13.Том 2. 2021.}

та незадовільного функціювання наявних на той час форм підготовки цих кадрів в республіці масово відкривалися такі кафедри, і станом на 1923 р. нараховувалося 88 науково-дослідних кафедр із загальною кількістю аспірантів 535 осіб (Тарнавська, 2010).

У підготовку аспірантів суттєву роль внесли три науково-дослідні кафедри педології: Київська, Харківська, Одеська (Тарнавська, 2010). Нормативний термін підготовки аспірантів при цих кафедрах становив два роки, i аспіранти зобов'язані були складати 2 екзамени: «політмінімум» $\mathrm{i}$ українську мову.

Приміром, у Київському інституті народної освіти навчання аспірантів здійснювалося за розробленою програмою, до складу якої входили такі теми та види робіт: «1) «Політичний мінімум»; 2) «Дитячий та юнацький рух»; 3) «Основи історії виховання»; 4) читання найновішої літератури з педології та педагогіки; реферування та розв'язання окремих питань; 5) теоретичні та практичні заняття 3 методів колективного й індивідуального дослідження дитини; 6) участь у науковій діяльності кафедри; 7) невелика напівсамостійна робота за завданнями кафедри; 8) самостійна робота» (Башкір, 2019, с.159).

У 1926-1927 н. p. програма навчання аспірантів була дещо звужена i передбачала семінари з фізіології, рефлексології, з науки про поведінку (психологія в історичному аспекті, методи психології, відчуття, сприймання, пам'ять, практична робота з психології), експериментальну педагогіку, семінар з логіки (Башкір, 2019).

Як самостійний науковий підрозділ аспірантура з педагогіки почала функціонувати у 1926 р. у створеному Українському Науково-Дослідчому Інституті Педагогіки (УНДІПі) в Харкові. І вже на кінець грудня 1926-го року в аспірантурі налічувалося 49 аспірантів (Попов, 1929).

Директор інституту - педагог, організатор освіти Олександр Попов у 1929 р. в журналі «Шлях освіти» схарактеризував діяльність Інституту й, зокрема, аспірантури за перші роки ії існування.

Так, в складі Інституту була учбова частина, що провадила навчально-підготовчу роботу 3 аспірантами (проведення загальнообов'язкових семінарів, практичних занять, вивчення чужоземних мов тощо); лабораторія експериментальної педагогіки, в якій виконувалась як суто науково-дослідча діяльність, так і практикум для аспірантів; фото-лабораторія, в якій було зосереджено досить цінне фотографічне приладдя (кілька фотографічних апаратів, апарат для збільшення тощо), яке використовували аспіранти для наукової роботи; книгозбірня, 46 тис. томів науково-педагогічної літератури, які були у вільному доступі (Попов, 1929).

Навчання в аспірантурі УНДІПу тривало три роки, упродовж яких аспірант вивчав іноземні мови, проходив педагогічну практику у закладі вищої освіти, займався самостійним виконанням науково-дослідної роботи під керівництвом наукового керівника. Крім теоретичної підготовки, велике значення надавалося питанням практичного застосування 


\section{Інноватика у вихованні. Випуск 13.Том 2. 2021.}

аспірантом отриманих у ході дослідження результатів. Виконана аспірантом наукова праця, за рекомендацією предметної комісії, повинна була представлятися на захист, який проводився на відкритому засіданні предметної комісії (Васильев, 2005). Особи, які успішно закінчили аспірантуру, здобували право викладання у ЗВО у якості асистентів або доцентів.

В аспірантуру приймали осіб у віці від 20 до 35 років, як 3 вищою освітою, так і тих, які не мали вищої освіти, але володіли необхідними для аспіранта знаннями (Ананов, 1928, с. 22-23). При цьому згідно із законом про обов'язкову військову службу аспірантам надавалася відстрочка від призову в армію на термін до трьох років і вони звільнялися також від проходження табірних зборів. Перший випуск Інституту становив 15 аспірантів - осіб цілком готових до самостійної наукової праці. В подальшому Інститут випускав до 20 аспірантів щороку.

Уже у 1929 р. в Інституті навчалося 75 аспірантів, якими керували дійсні члени та керівники секцій. Підготовка аспірантів здійснювалася через систему семінарів та практичних занять. Як зазначав О. Попов, для всіх аспірантів обов'язковими були такі семінари: 1) 3 неврології та рефлексології, 2) 3 марксизму та ленінізму, 3) 3 методики і техніки педагогічного експерименту та 3 загальної педагогіки 3 історією педагогіки і освіти. Семінари проводилися протягом перших двох років навчання. Одночасно аспіранти вивчали чужоземні мови та проходили додаткові спеціальні семінари при відділах та секціях. Протягом останнього року аспірант працював переважно в галузі науково-дослідчій, «обробляючи» свою наукову працю, захист якої планувався на кінець третього року, у результаті він отримував звання наукового співробітника, а також на нього покладався обов'язок проводити педагогічний практикум в педагогічному виші (Попов, 1929).

Якісній підготовці аспірантів сприяв досить тісний зв'язок з науковопедагогічною громадськістю та освітніми установами України, СРСР та закордону. Науково-педагогічні установи Москви, Ленінграду, деяких міст Західної Свропи і Америки перебували в «листовних і безпосередніх» зв'язках з Інститутом.

У 1929-1930 н. p. аспірантура працювала за затвердженим навчальним планом, програмами загальноінститутських семінарів. I хоч план мав багато недоліків, все ж це був перший навчальний план аспірантури.

Основними засадами побудови плану були такі:

1. Кількість семінарів, що їх проходив аспірант протягом академічного року, була невелика -2-3.

2. План мав бути складений так, щоб ураховувався не лише час, потрібний для проходження того чи іншого семінару, а також i час, необхідний для підготовки, відвідування різних засідань тощо.

3. Перший рік аспірант зобов'язаний був приділяти більше часу загальноінститутським дисциплінам і менше-спеціальним. Другий рік - 


\section{Інноватика у вихованні. Випуск 13.Том 2. 2021.}

навпаки, а третій, крім секційної роботи, залишався переважно для написання дисертаційної праці та педагогічної практики.

4. Хоча кожен аспірант в перший же рік повинен обрати собі секцію, в якій він хотів би виконувати свою наукову роботу, але теми для дисертаційної роботи він міг ще точно не формулювати. На другий рік аспірант повинен вже був визначитися 3 темою, над якою й починав працювати.

Для аспірантів другого й третього року навчання навчальним планом передбачалася можливість, в залежності від вільного часу, пройти семінари, яких вони не встигли відвідати у попередні роки свого навчання.

Підготовка аспірантів здійснювалася за принципом, що «наукового робітника, який не знав би жодної чужоземної мови, не можна собі уявити», тому в навчальний план було введено дві мови - німецьку та англійську, з яких аспірант міг вивчати одну чи дві за власним бажанням (Попов, 1929).

Навчальні плани представлені у таблицях 1-3.

Таблиця 1

Навчальний план для аспірантів I року

\begin{tabular}{|l|l|l|l|}
\hline 1. & $\begin{array}{l}\text { Семінар з науки про поведінку 3 анатомо- } \\
\text { фізіологічним вступом до нього }\end{array}$ & год. & на декаду \\
\hline 2. & Семінар з марксизму & 4 год. & на декаду \\
\hline 3. & Чужоземна мова & 6 год. & на декаду \\
\hline 4. & Загальноінститутські засідання & 4 год. & на декаду \\
\hline 5. & Секційна робота & 3 год. & на декаду \\
\hline 6. & Громадське навантаження робота (підготовка до & 2 год. & на декаду \\
\hline 7. & $\begin{array}{l}\text { Самостійна род } \\
\text { емінарів, доповідей, взагалі наукова } \\
\text { робота тощо) }\end{array}$ & на декаду \\
\hline & \multicolumn{3}{|l}{} \\
\hline
\end{tabular}

(Попов, 1929).

Таблиця 2

Навчальний план для аспірантів II року

\begin{tabular}{|c|l|l|l|}
\hline 1. & Семінар 3 марксизму & 4 год. & на декаду \\
\hline 2. & $\begin{array}{l}\text { Семінар з науки про поведінку (протягом } \\
\text { першого семестру, а для тих, хто в } \\
\text { минулому році не проходив, протягом } \\
\text { цілого року) }\end{array}$ & на декаду \\
\hline 3. & $\begin{array}{l}\text { Семінар з теорії педвимірів та } \\
\text { експерименту }\end{array}$ & год. & на декаду \\
\hline 4. & Семінар з педагогічного експерименту & 2 год. & на декаду \\
\hline 5. & Чужоземна мова & 6 год. & на декаду \\
\hline 6. & Загальноінститутскі засідання & 4 год. & на декаду \\
\hline 7. & Секційна робота & 3 год. & на декаду \\
\hline 8. & Громадське навантаження & 4 год. & на декаду \\
\hline 9. & Самостійна робота & $19-22$ & на декаду \\
\hline
\end{tabular}




\begin{tabular}{|l|l|l|l|}
\hline & & год. & \\
\hline & & Разом 48 на декаду \\
\hline
\end{tabular}

(Попов, 1929).

Таблиця 3

Навчальний план для аспірантів III року

\begin{tabular}{|l|l|l|l|}
\hline 1. & Практикум у лябораторії & 2 год. & на декаду \\
\hline 2. & Семінар з історії педагогіки & 3 год. & на декаду \\
\hline 3. & Мова & 6 год. & на декаду \\
\hline 4. & Загальноінститутські засідання & 4 год. & на декаду \\
\hline 5. & Секційна робота & 3 год. & на декаду \\
\hline 6. & Громадське навантаження & 4 год. & на декаду \\
\hline 7. & Самостійна робота & 26 год. & на декаду \\
\hline & \multicolumn{3}{|l}{} \\
\hline
\end{tabular}

(Попов, 1929).

Окремим аспірантам як педагогічну практику зараховували роботу у вишах, однак вважалося, що це не зовсім гарний досвід, оскільки така робота була не пов'язана 3 навчальним планом аспіранта i не контролювалася відділом аспірантури, що не сприяло іiі якості й плановості (Попов, 1929).

Основними недоліками навчального плану директор Інституту О. Попов вважав його «непристосованість до тих дисциплін, що викладаються по педвишах взагалі й відсутність будь-якої специфікації для підготування до праці по тому чи іншому відділу зокрема» (Попов, 1929). На перспективу передбачалося внести зміни в навчальний план, аби наукові семінари були пристосовані до тих дисциплін, які викладаються у педвишах; і щоб він був досить гнучким, аби кожен аспірант, крім деяких загальних, проходив ті семінари, які будуть потрібні йому для його дослідження і педагогічної роботи у виші, тобто передбачалося укласти декілька планів, «специфічних для соцвихника, для профосвітника, політосвітника тощо» (Попов, 1929).

У 1930 р. в Україні аспірантури як окремі структурні одиниці вже функціонували, окрім УНДІПу (Харків), у його філії в Києві, Інституті фізичної культури (Харків) та його філії в Одесі.

Необхідно зазначити, що до початку $30-\mathrm{x}$ рр. не існувало чітких інструкцій щодо форм і методів організації навчання в аспірантурі, керівництва аспірантами, відповідальності за їхню підготовку тощо. Не було ясності в питаннях про критерії успішного навчання в аспірантурі й необхідності захисту кваліфікаційної роботи. Саме 1930-ті рр. стали періодом активного організаційного формування інституту аспірантури: в квітні 1930 р. було введено посаду зав. аспірантурою, в обов'язки якого входила організаційна й науково-методична робота з аспірантами; 19 вересня 1932 р. було прийнято Постанову ЦВК СРСР «Про навчальні програми й режими у вищій школі й технікумах», якою визначалися 


\section{Інноватика у вихованні. Випуск 13.Том 2. 2021.}

методи керівництва й форми роботи аспірантури: заняття аспірантів за індивідуальними планами роботи, обов'язкове відвідування аспірантами занять 3 марксистського мінімуму, педагогіки, іноземних мов, відповідальність наукових керівників за стан аспірантської підготовки; у 1932 р. для наукових керівників була введена оплата за керівництво аспірантами (Про навчальні програми та режим у вищій школі та технікумах, 1961). До цього моменту вони виконували цю роботу на громадських засадах.

У січні 1934 р. була прийнята Постанова уряду «Про підготовку наукових і науково-педагогічних працівників», на основі якої вводилися регулярні щорічні перевірки успішності аспірантів (згодом атестації), чітко була визначена освітня складова аспірантської підготовки, i закріплювалася практика представлення й публічного захисту аспірантами дисертаційної роботи (О подготовке научных и научно-педагогических работников, 1934). Відповідно до нових правил аспіранти допускалися до захисту дисертації тільки після здачі кандидатських іспитів, що включали екзамен з загальної дисципліни, яку визначала спеціальність аспіранта в цілому, з іншої дисципліни - більш вузької спеціалізації, яка відповідала його інтересам, а також 3 діалектичного й історичного матеріалізму й іноземної мови (Климов, 2004, с. 124).

Досить важливим було те, що Постановою «Про розмір стипендій для аспірантів втузів, вузів і науково-дослідних інститутів» (27 квітня 1933 р.) аспірантам нараховувалася стипендія, в середньому 200 крб.; для осіб, які демонстрували особливі досягнення - 250-300 крб. Для порівняння: зарплата викладача університету становила на той час 336 крб. (О размере стипендий для аспирантов втузов, вузов и научно-исследовательских институтов, 1933). У 1937 р. державна стипендія вже була встановлена в розмірі 400 крб. на місяць, тобто аспірант у середині 30 -х рр. минулого століття одержував стипендію навіть більшу, ніж середня зарплата викладача університету, й майже в два рази більшу, ніж середня зарплата по країні.

Науково-навчальна робота аспіранта проводилася за індивідуальним планом, основним змістом якого були самостійні науково-дослідні й педагогічні роботи аспіранта, що завершувалися захистом дисертації на ступінь кандидата наук. Згідно з планом підготовки на першому році навчання аспірант повинен був займатися вивченням іноземних мов (не менше двох), марксистсько-ленінської методології, а також самостійною роботою зі спеціальності з консультуванням у керівника й відвідуванням лекцій. На другому році до цього додавалася педагогічна робота. 3 цього ж року розпочиналася робота над дисертацією. Третій рік переважно був присвячений роботі над дисертацією 3 консультуванням у керівника, а також невеликій педагогічній діяльності. Близько $20-25 \%$ робочого часу аспіранта виділялося на роботу з керівником (консультації, семінари, лекції) і 75-80\% - на самостійну роботу з теми дослідження (Климов, 2004). 


\section{Інноватика у вихованні. Випуск 13.Том 2. 2021.}

Основні принципи функціонування аспірантури були закріплені в першому радянському Положенні про аспірантуру, прийнятому РНК СРСР 31 березня 1939 р. Саме за цим положенням до одного наукового керівника прикріплялося не більше 5 аспірантів. Захист дисертації був основною метою й головним критерієм ефективності аспірантури. Це Положення передбачало вивчення двох іноземних мов, а всі наступні одного. У цьому Положенні вперше були встановлені вимоги до наукового керівника: керівниками призначалися співробітники організації, що мали науковий ступінь доктора наук або звання професора (Абакумов, Кузин, Пузырев и Литвинов, 1974). Відзначимо, що положення 1939 р. встановлювало проведення занять для аспірантів і перелік дисциплін.

Таким чином, на початку свого існування модель аспірантури в СРСР була «освітньою».

У роки Другої світової війни аспірантури практично припинили своє існування, а в 1944 р. поступово почали відновлювати свою діяльність. Керуючись прийнятим у 1948 р. наказом «Про міри 3 покращення підготовки науково-педагогічних кадрів через аспірантуру», інститути УРСР приділяли серйозну увагу індивідуальній роботі 3 аспірантами, підготовці ними дисертацій (Бюллетень МВО СССР, 1948). Тільки в УНДІПі, наприклад, за період 1946-1950 pp. було підготовлено й захищено 11 кандидатських дисертацій (Вакуленко та Уманська, 1954, c.10).

Постановою ВАКу від 11 жовтня 1948 р. «Про підсумки роботи 3 атестації наукових кадрів за 1947/1948 навчальний рік» був уведений обов'язковий автореферат дисертації. Згідно з Постановою він повинен був бути розмножений в кількості 100 екземплярів і розісланий не пізніше одного місяця до захисту зацікавленим особам (Выскуб, 2005, с. 47).

У 1953 р. Постановою РМ СРСР «Про заходи щодо поліпшення підготовки професорсько-викладацьких кадрів для вищих навчальних закладів СРСР» було дещо змінено умови зарахування в аспірантуру: в очну аспірантуру приймалися громадяни СРСР не старше 40 років, у заочну - без обмежень за віком. Для вступу в аспірантуру кандидати складали три іспити (спеціальність, основи марксизму-ленінізму й іноземна мова). Тільки тепер ці іспити здавалися не одній загальній комісії, як раніше, а трьом різним приймальним комісіям (О мерах по улучшению подготовки профессорско-преподавательских кадров для высших учебных заведений СССР, 1953).

У 1956 р. відбулися значні зміни в галузі підготовки наукових i науково-педагогічних кадрів через аспірантуру: 320 серпня згідно 3 Постановою ЦК КПРС і РМ СРСР «Про заходи щодо поліпшення підготовки й атестації наукових і науково-педагогічних кадрів», такими, що закінчили аспірантуру, стали вважатися особи, що виконали затверджений індивідуальний план аспірантської підготовки й одержали позитивну оцінку своєї наукової роботи, результати якої були повідомлені на раді закладу або НДІ. Таким чином, тепер не був потрібний захист 
кандидатської дисертації. Аспірантові, що виконав зазначені вище вимоги, видавалося посвідчення особливої форми про закінчення аспірантури. Однак для того, щоб бути допущеним до захисту дисертації й в результаті отримати вчений ступінь, аспірантові необхідно було опублікувати дисертацію у вигляді монографії або окремих статей. Крім того, аспірант мав право захищати дисертацію тільки через три місяці після виходу його наукової публікації з друку (Про заходи щодо поліпшення підготовки й атестації наукових і науково-педагогічних кадрів, 1961).

Отже, здійснений аналіз дає змогу зробити висновок, що розвиток аспірантури у 50-ті pp. XX століття пішов шляхом скорочення освітньої підготовки й трансформувався в «дослідницьку» модель.

Починаючи з 1962 р., у відповідно до «Положення про аспірантуру при вищих навчальних та науково-дослідних установах» замість теоретичних занять з'явилося поняття «здача кандидатських іспитів»; при цьому механізм підготовки до кандидатських іспитів ні в Положенні 1962 p., ні в подальших положеннях прописаний не був (Положение об аспирантуре при высших учебных заведениях и научно-исследовательских учреждениях, 1965). На основі «Положення про аспірантуру» було визнано за доцільне повернутися до раніше прийнятих умов закінчення аспірантури з обов'язковим захистом дисертації або представленням до захисту. Однак правило про обов'язкову публікацію аспірантами результатів своїх досліджень при цьому скасоване не було.

У 1987 р. було затверджено нове єдине для всієї системи підготовки наукових і науково-педагогічних кадрів, у тому числі й для аспірантури, «Положення про підготовку науково-педагогічних і наукових кадрів у системі безперервної освіти». В план аспірантської підготовки вводилися нові дисципліни. Крім вивчення педагогіки й психології, відтепер аспірант також повинен був опанувати методами використання обчислювальної техніки, математичного моделювання й інших дисциплін і здати відповідні іспити (Климов, 2004, с. 137-139).

Випускникам аспірантури, які виконали свій індивідуальний навчальний план, присвоювалась кваліфікація «дослідник» відповідного профіля, вручався диплом, але для отримання наукового ступеня кандидата наук потрібно було захистити дисертацію. Саме тепер почали зараховувати стаж навчання в аспірантурі до стажу науково-педагогічної роботи (Бюллетень МВ и ССО СССР, 1987).

Відповідальність за підготовку аспірантів і загальне керівництво аспірантами покладалось на відповідні кафедри (1934); на завідувача кафедри (1939); на керівників установ, у яких навчалися аспіранти й Вчені ради $(1962,1980)$; на Вчені ради (1987). Таким чином, відповідальність за підготовку аспірантів поступово стала носити загальний, а не персональний характер.

Порівняння змісту освітньої підготовки аспірантів в різні роки представимо у вигляді таблиці 4. 
Інноватика у вихованні. Випуск 13.Том 2. 2021.

Таблиця 4

Зміст діяльності аспірантури, встановлений нормативними документами різних років

\begin{tabular}{|c|c|}
\hline 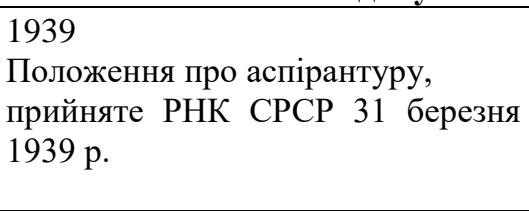 & $\begin{array}{l}1962 \\
\text { Положення про аспірантуру при } \\
\text { вищих навчальних і науково- } \\
\text { дослідних установах, затверджене } \\
\text { 31липня } 1962 \text { р. }\end{array}$ \\
\hline $\begin{array}{l}\text { Теоретичні заняття з однієї } \\
\text { соціально-економічних } \\
\text { дисциплін, з 2-х іноземних мов, з } \\
\text { 2-х спеціальних дисциплін. } \\
\text { Участь у методичній роботі } \\
\text { кафедри, відвідування лекцій і } \\
\text { занять досвідчених викладачів. } \\
\text { Самостійне виконання наукової } \\
\text { роботи. } \\
\text { Проходження науково-виробничої } \\
\text { практики після 1-го року } \\
\text { навчання. } \\
\text { Підготовка й захист дисертації. }\end{array}$ & 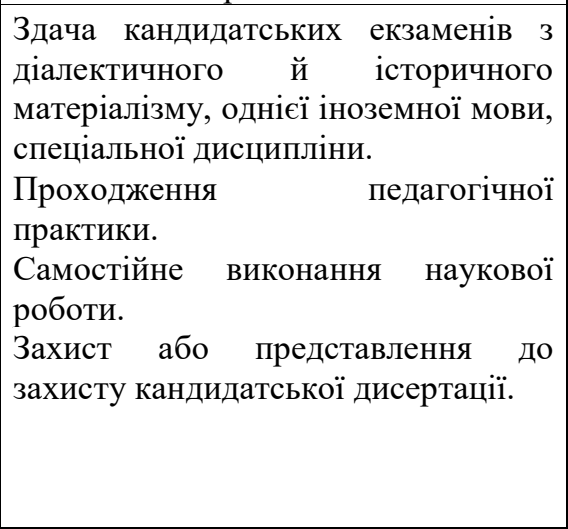 \\
\hline $\begin{array}{l}\text { Постанова ЦК КПРС і Ради } \\
\text { міністрів СРСР «Про заходи щодо } \\
\text { покращення підготовки } \\
\text { використання } \\
\text { педагогічних і наукових кадрів» } \\
\text { № } 327 \text { від } 13 \text { березня } 1987 \text { p. }\end{array}$ & $\begin{array}{l}2016 \\
\text { Про затвердження Порядку } \\
\text { підготовки здобувачів вищої освіти } \\
\text { ступеня доктора філософії та } \\
\text { доктора наук у закладах вищої } \\
\text { освіти (наукових установах)» зі } \\
\text { змінами, внесеними згідно з } \\
\text { Постановою КМ № } 283 \\
\text { 03.04.2019 р. }\end{array}$ \\
\hline 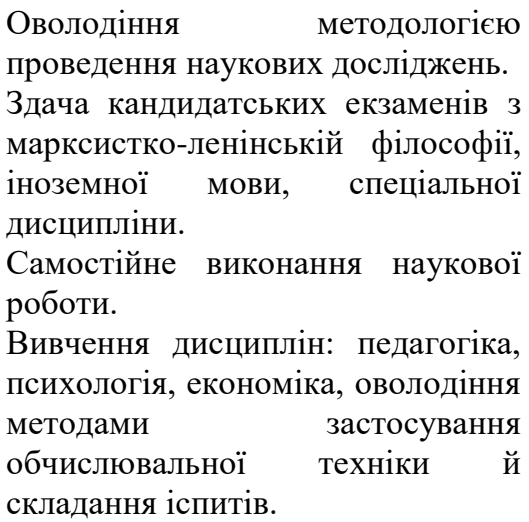 & 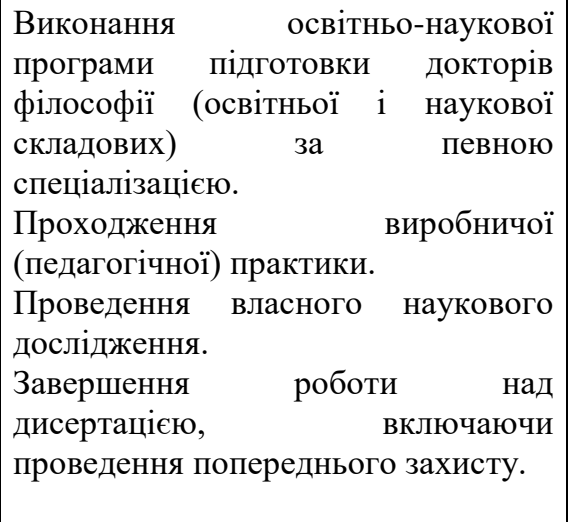 \\
\hline
\end{tabular}

У 90-ті роки ХХ ст. вносилися лише незначні зміни в правила прийому до аспірантури. Усі вступники повинні були скласти три вступні 


\section{Інноватика у вихованні. Випуск 13.Том 2. 2021.}

іспити (спеціальність, філософію, іноземну мову) і представити письмовий реферат або опубліковану роботу з вибраної спеціальності. Перескладання вступних іспитів не допускалося. Особи, які повністю або частково здали кандидатські іспити до вступу в аспірантуру, надавали про це посвідчення за встановленою формою. При цьому вони звільнялися від вступних іспитів в аспірантуру, але зобов'язані були представити реферат 3 вибраної спеціальності (Войленко, Гейхман и Рубцов, 1980).

Фактично за цими правилами аспірантури працювали до початку 2000-х pp., а дійсно змістове оновлення діяльності аспірантури розпочалося у 2016 р., коли була прийнята Постанова Кабінету Міністрів України № 261 «Про затвердження Порядку підготовки здобувачів вищої освіти ступеня доктора філософії та доктора наук у закладах вищої освіти (наукових установах)» (Про затвердження Порядку підготовки здобувачів вищої освіти ступеня доктора філософії та доктора наук у закладах вищої освіти (наукових установах), 2016).

Відповідні зміни знайшли своє відображення в освітньо-наукових програмах підготовки доктора філософії, наприклад, за спеціальністю 011 «Освітні, педагогічні науки» (Освітньо-наукова програма підготовки доктора філософії за спеціальністю 011 «Освітні, педагогічні науки», 2020). Підготовка докторів філософії на нових засадах вдосконалюється й корегується.

Висновки і перспективи подальших розвідок. Таким чином, здійснений аналіз уможливлює висновок про те, що становлення інституту аспірантури пройшло декілька етапів. 3 моменту утворення аспірантури в 1925 р. і до початку 1930-х рр. принципи роботи цього інституту 3 підготовки наукових і науково-педагогічних кадрів були ще невизначені й законодавчо недосконалі. Упродовж 1930-х рр. відбувалися пошуки найбільш ефективних форм і методів організації аспірантської підготовки. Їхні результати були відображені в першому радянському Положенні про аспірантуру 1939 р., де викладалися основні принципи роботи аспірантури.

Друга світова війна перервала діяльність аспірантур. У перше післявоєнне десятиліття була здійснена масштабна робота з розробки й законодавчого закріплення принципів роботи аспірантури, що стало основою для подальшого розвитку цього інституту в нашій країні. Упродовж 1960-1980-х рр. вони лише частково видозмінювалися й удосконалювалися.

Усього ж у післявоєнний період було прийнято п’ять Положень (1950, 1957, 1962, 1980, 1987 рр.), що регулювали підготовку наукових і науковопедагогічних кадрів через аспірантуру.

Змістове оновлення діяльності аспірантури розпочалося у 2016 р., коли була прийнята Постанова Кабінету Міністрів України № 261 «Про затвердження Порядку підготовки здобувачів вищої освіти ступеня доктора філософії та доктора наук у закладах вищої освіти (наукових установах)». 


\section{Інноватика у вихованні. Випуск 13.Том 2. 2021.}

Вважаємо, що актуальність звернення до досліджуваної проблеми 3 метою вивчення питання організації аспірантури, причин їі певної структурної організації, механізмів регулювання й керування, зафіксованих у документальній базі іiі існування упродовж майже ста років безсумнівна, оскільки дає змогу не лише проаналізувати чинну систему підготовки кадрів через аспірантуру в пї історико-педагогічній ретроспективі, але й спрогнозувати ті можливі результати при доведенні реформування до певної крапки біфуркації, коли існування цієї системи стає неможливим.

У перспективі, на нашу думку, подальшого вивчення потребують особливості здійснення наукового керівництва дослідженнями аспірантів в 1920- 2020 pp.

\section{СПИСОК ВИКОРИСТАНИХ ДЖЕРЕЛ}

Лебин, Б. (1966). Подбор, подготовка и аттестация научных кадров в СССР. Вопросы истории и правового регулирования. М., Лен.: Наука, 1966. $288 \mathrm{c}$.

Кононова, С. (2005). Становление и развитие государственной системы подготовки научных кадров через аспирантуру в России : 1918 2004. Кандидат педагогических наук. Невинномысский государственный гуманитарно-технический институт.

Ільницьким, Р. та Процишина, Н. (2016). Зміст підготовки аспірантів у вищих навчальних закладах України. Науковий вісник Східноєвропейського національного університету імені Лесі Украӥнки. Педагогічні науки. № 2. СС. 44-52.

Филатова, А. (2010). Приоритетные направления государственной политики СССР в сфере подготовки научных кадров в 1960-1980-е гг. Вестник Российского университета дружбь народов. Серия «История». № 2. CC. 31-39.

Справочник аспиранта. (1928). М.: РАНИОН. 156 с.

Иванова, Л. (1980). Формирование советской научной интеллигенциии (1917- 1927 г2.). М. 249 с.

Лескова, Н. (2012). Сигурд Шмидт: «Слово «аспирант» придумал мой отец». Газета «Культура». URL: http://portalkultura.ru/articles/history/sigurd-shmidt-slovo-aspirant-pridumal-moy-otets-vkabinete-lenina/ [Дата обращения 7.05.21].

Вищуа школа УРСР за 50 років: в 2 ч. (1967). Київ. Ч. 1 (1917-1945). 394 c.

Временное положение о Высших Учебных заведениях У.С.С.Р. (1922). Том 1. Временное Положение об Институтах. Харьков, 45 с.

Тарнавська, С. (2010). Організація та діяльність науково-дослідних кафедр в Україні в 1920-ті роки. Вісник Київського національного університету імені Тараса Шевченка. № 99. СС. 53-56.

Башкір, О. (2019). Науково-педагогічна діяльність кафедр педагогіки у вищих педагогічних навчальних закладах України (початок XX-початок 


\section{Інноватика у вихованні. Випуск 13.Том 2. 2021.}

XXI століття). Доктор педагогічних наук. Харківський національний педагогічний університет імені Г. С. Сковороди.

Попов, О. (1929). Український Науково-Дослідчий Інститут Педагогіки в Харкові. Шлях освіти. № 8-9. СС. 130-138.

Васильев, Д. (2005). Так выращивались научно-педагогические кадры высшей школы. Alma mater (Вестник высшей школы). № 9. СС. 46-49.

Ананов, И. (1928). Правовое положение научных работников. М.: Нижполиграф. 59 с.

Про навчальні програми та режим у вищій школі та технікумах. (1961). Найважливімі рімення КП і Радянського Уряду. 1917-1960 рр. $3 б$. документів. В $2 x$ т. К., Т. 1. (1917 - червень 1941). СС. 593-604.

О подготовке научных и научно-педагогических работников. (1934). URL: https://www.lawmix.ru/sssr/15534. [Дата обращения 7.05.21].

Климов, А. (2004). История кандидатских экзаменов в нормативных правовых актах России (1802-2004). Кандидат исторических наук. Пятигорск.

O размере стипендий для аспирантов втузов, вузов и научноисследовательских институтов. (1933). URL: http://www.libussr.ru/doc_ussr/ ussr_3882.htm. [Дата обращения 7.05.21].

Абакумов, А., Кузин Н., Пузырев, Ф. и Литвинов Л. (1974). Положение об аспирантуре, утвержденное СНКСССР от 31 марта 1939 г. Народное образование в СССР. Сборник документов 1917-1973 г2. М.: Педагогика. СС. 238-240.

Бюллетень МВО СССР. (1948). № 4. СС. 6-9.

Вакуленко, Н. та Уманська, Л. (1954). Науково-дослідні інститути Міністерства освіти УРСР у першій післявоєнній п'ятирічці. Радянська школа. № 11. СС. 3-11.

Выскуб, В. (2005). Российская общественно-государственная система аттестации научных и научно-педагогических кадров высшей квалификации. М.: Логос, 256 с.

О мерах по улучшению подготовки профессорско-преподавательских кадров для высших учебных заведений СССР. (1953). Бюллетень Главного управления высшего образования Министерства культуры СССР. № 6. CC. $2-4$.

Про заходи щодо поліпшення підготовки й атестації наукових $\mathrm{i}$ науково-педагогічних кадрів. (1961). Культурне будівництво в Украӥнській РСР. Збірник. док. і матеріалів. К.: Вища школа, Т. ІІ (червень $1941-1960$ pp.). CC. 338.

Положение об аспирантуре при высших учебных заведениях и научно-исследовательских учреждениях. (1965). Высшая школа: Сб. осн. постановлений, приказов и инструкций. М. Т. 1. С. 279.

Климов, А. (2004). История кандидатских экзаменов в нормативных правовых актах России (1802-2004). Кандидат исторических наук. Пятигорск.

Бюллетень МВ и ССО СССР. (1987). № 12. СС. 7-13. 


\section{Інноватика у вихованні. Випуск 13.Том 2. 2021.}

Войленко, Е., Гейхман, В. и Рубцов А.В. (1980). Справочник по правовым вопросам высшей школьы. К.: Вища школа, 384 с.

Про затвердження Порядку підготовки здобувачів вищої освіти ступеня доктора філософії та доктора наук у закладах вищої освіти (наукових установах) (2016). URL: https://zakon.rada.gov.ua/laws/show/2612016-\%D0\%BF\#Text. [Дата звернення 7.05.21].

Освітньо-наукова програма підготовки доктора філософії за спеціальністю 011 «Освітні, педагогічні науки». (2020). URL: https://www.rshu.edu.ua/images/osvitni_programi/osv_prog_dokt_011_opn_20 20.pdf. [Дата звернення 7.05.21].

\section{REFERENCES}

Lebin, B. (1966). Podbor, podgotovka i attestatsiya nauchnykh kadrov $v$ SSSR. Voprosy istorii $i$ pravovogo regulirovaniya. [Selection, training and attestation of scientific staff in the USSR. Issues of history and legal regulation]. M., Len. : Nauka, 1966. 288 c. [in Russian].

Kononova, S. (2005). Stanovlenie $i$ razvitie gosudarstvennoy sistemy podgotovki nauchnykh kadrov cherez aspiranturu v Rossii : 1918-2004. [Formation and development of the state system of training scientific staff in postgraduate studies in Russia: 1918-2004]. Kandidat pedagogicheskikh nauk. Nevinnomysskiy gosudarstvennyy gumanitarno-tekhnicheskiy institut. [in Russian].

Ilnytskym, R. \& Protsyshyna, N. (2016). Zmist pidhotovky aspirantiv u vyshchykh navchalnykh zakladakh Ukrainy. [The content of postgraduate training in higher educational institutions of Ukraine]. Naukovyi visnyk Skhidnoievropeiskoho natsionalnoho universytetu imeni Lesi Ukrainky. Pedahohichni nauky. No 2. SS. 44-52. [in Ukrainian].

Filatova, A. (2010). Prioritetnye napravleniya gosudarstvennoy politiki SSSR v sfere podgotovki nauchnykh kadrov v 1960-1980-e gg. [Priority directions of the state policy of the USSR in the field of training scientific personnel in the 1960s - 1980s.]. Vestnik Rossiyskogo universiteta druzhby narodov. Seriya "Istoriya". No 2. SS. 31-39. [in Russian].

Spravochnik aspiranta. [Handbook of a postgraduate student]. (1928). M.: RANION. 156 s. [in Russian].

Ivanova, L. (1980). Formirovanie sovetskoy nauchnoy intelligentsii (1917$1927 \mathrm{gg}$.). [Formation of the Soviet scientific intelligentsia (1917-1927)]. M. 249 s. [in Russian].

Leskova, N. (2012). Sigurd Shmidt: "Slovo "aspirant" pridumal moy otets». [Sigurd Schmidt: "The word" postgraduate student" was invented by my father]. Gazeta "Kultura”. URL: http://portal-kultura.ru/articles/history/sigurdshmidt-slovo-aspirant-pridumal-moy-otets-v-kabinete-lenina.

[Data obrashcheniya 7.05.21]. [in Russian].

Vyshcha shkola URSR za 50 rokiv: v 2 ch. (1967). [Higher school of the UkrSSR for 50 years: in 2 parts]. K. Ch. 1 (1917-1945). 394 s. [in Ukrainian]. 


\section{Інноватика у вихованні. Випуск 13.Том 2. 2021.}

Vremennoe polozhenie o Vysshikh Uchebnykh zavedeniyakh U.S.S.R. (1922). [Temporary Regulation on Higher Educational Institutions of the U.S.S.R]. Tom 1. Vremennoe Polozhenie ob Institutakh. Kh., 45s. [in Russian].

Tarnavska, S. (2010). Orhanizatsiia ta diialnist naukovo-doslidnykh kafedr v Ukraini v 1920-ti roky. [Organization and activity of research departments in Ukraine in the 1920s.] Visnyk Kyivskoho natsionalnoho universytetu imeni Tarasa Shevchenka. No 99. SS. 53-56. [in Ukrainian].

Bashkir, O. (2019). Naukovo-pedahohichna diialnist kafedr pedahohiky u vyshchykh pedahohichnykh navchalnykh zakladakh Ukrainy (pochatok XX pochatok XXI stolittia). [Scientific and pedagogical activity of departments of pedagogy in higher pedagogical educational institutions of Ukraine (beginning of the $20^{\text {th }}$ - beginning of the 21 st century). Doktor pedahohichnykh nauk. Kharkivskyi natsionalnyi pedahohichnyi universytet imeni H. S. Skovorody. [in Ukrainian].

Popov, O. (1929). Ukrainskyi Naukovo-Doslidchyi Instytut Pedahohiky v Kharkovi. [Ukrainian Research Institute of Pedagogy in Kharkiv]. Shliakh osvity. No 8 -9. SS. 130-138. [in Ukrainian].

Vasilev, D. (2005). Tak vyrashchivalis nauchno-pedagogicheskie kadry vysshey shkoly. [How the scientific and pedagogical staff of the higher school was trained]. Alma mater (Vestnik vysshey shkoly). No 9. SS. 46-49. [in Russian].

Ananov, I. (1928). Pravovoe polozhenie nauchnykh rabotnikov [Legal status of scientists]. Moskva: Nizhpoligraf. 59 s. [in Russian].

Pro navchalni prohramy ta rezhym u vyshchii shkoli ta tekhnikumakh. (1961). [About curricula and regime in higher and technical schools]. Naivazhlyvishi rishennia KP $i$ Radianskoho Uriadu. 1917-1960 rr. Zb. dokumentiv. V 2kh t. Kyiv, T. 1. (1917 - cherven 1941). SS. 593-604. [in Ukrainian].

O podgotovke nauchnykh i nauchno-pedagogicheskikh rabotnikov. [About training of scientific and scientific and pedagogical staff]. (1934). URL: https://www.lawmix.ru/sssr/15534. [Data obrashcheniya 7.05.21]. [in Russian].

Klimov, A. (2004). Istoriya kandidatskikh ekzamenov $v$ normativnykh pravovykh aktakh Rossii (1802-2004). [History of candidate examinations in normative legal acts of Russia (1802-2004)]. Kandidat istoricheskikh nauk. Pyatigorsk. [in Russian].

$O$ razmere stipendiy dlya aspirantov vtuzov, vuzov $i$ nauchnoissledovatelskikh institutov. [About the amount of scholarships for graduate students of universities, colleges and research institutes]. (1933). URL: http://www.libussr.ru/doc_ussr/ ussr_3882.htm. [Data obrashcheniya 7.05.21]. [in Russian].

Abakumov, A., Kuzin N., Puzyrev, F. i Litvinov L. (1974). Polozhenie ob aspiranture, utverzhdennoe SNK SSSR ot 31 marta 1939 g. [Regulations on postgraduate studies, approved by the Council of People's Commissars of the USSR dated March 31, 1939]. Narodnoe obrazovanie v SSSR. Sbornik dokumentov 1917-1973 gg. M/: Pedagogika. SS.238-240. [in Russian]. 
Biulleten MVO SSSR. [Bulletin of the MMD of the USSR.] (1948). No 4. SS. 6-9. [in Ukrainian].

Vakulenko, N. ta Umanska, L. (1954). Naukovo-doslidni instytuty Ministerstva osvity URSR u pershii pisliavoiennii piatyrichtsi. [Research institutes of the Ministry of Education of the USSR in the first postwar fiveyear plan]. Radianska shkola. No 11. SS. 3-11. [in Ukrainian].

Vyskub, V. (2005). Rossiyskaya obshchestvenno-gosudarstvennaya sistema attestatsii nauchnykh $i$ nauchno-pedagogicheskikh kadrov vysshey kvalifikatsii. [Russian public-state system of attestation of scientific and scientific-pedagogical staff of the highest qualification]. Moskva: Logos, $256 \mathrm{~s}$. [in Russian].

O merakh po uluchsheniyu podgotovki professorsko-prepodavatelskikh kadrov dlya vysshikh uchebnykh zavedeniy SSSR. (1953). [Measures to improve the training of teaching staff for higher educational institutions of the USSR]. Byulleten Glavnogo upravleniya vysshego obrazovaniya Ministerstva kultury SSSR. No 6. SS. 2-4. [in Russian].

Pro zakhody shchodo polipshennia pidhotovky y atestatsii naukovykh i naukovo-pedahohichnykh kadriv. [Measures for improvement of training and attestation of scientific and scientific and pedagogical staff]. (1961). Kulturne budivnytstvo v Ukrainskii PCP. Zbirnyk. dok. i materialiv. K.: Vyshcha shkola, T. II (cherven 1941-1960 pp.). S. 338. [in Ukrainian].

Polozhenie ob aspiranture pri vysshikh uchebnykh zavedeniyakh i nauchno-issledovatelskikh uchrezhdeniyakh. [Regulations on postgraduate studies at higher educational institutions and research institutions]. (1965). Vysshaya shkola: Sb. osn. postanovleniy, prikazov i instruktsiy. Moskva. T. 1. S. 279. [in Russian].

Klimov, A. (2004). Istoriya kandidatskikh ekzamenov v normativnykh pravovykh aktakh Rossii (1802-2004). [The history of candidate examinations in the normative legal acts of Russia (1802-2004)]. Kandidat istoricheskikh nauk. Pyatigorsk. [in Russian].

Biulleten MV y SSO SSSR. [Bulletin MV and SSO USSR]. (1987). No 12. SS. 7-13. [in Ukrainian].

Voylenko, Ye., Geykhman, V. i Rubtsov A.V. (1980). Spravochnik po pravovym voprosam vysshey shkoly. [Handbook on legal issues of higher education]. K. : Vyshcha shkola. 384 s. [in Russian].

Pro zatverdzhennia Poriadku pidhotovky zdobuvachiv vyshchoi osvity stupenia doktora filosofii ta doktora nauk $u$ zakladakh vyshchoi osvity (naukovykh ustanovakh). [About the statement of the Order of training of applicants of higher education of $\mathrm{PhD}$ and the doctor of sciences in institutions of higher education (scientific institutions). (2016). URL: https://zakon.rada.gov.ua/laws/show/261-2016-\%D0\%BF\#Text [Data zvernennia 7.05.21]. [in Ukrainian].

Osvitno-naukova prohrama pidhotovky doktora filosofii za spetsialnistiu 011 "Osvitni, pedahohichni nauky". [Educational and scientific program of $\mathrm{PhD}$ training in specialty 011 "Educational, pedagogical sciences"]. (2020). URL: 
https://www.rshu.edu.ua/images/osvitni_programi/osv_prog_dokt_011_opn_20 20.pdf. [Data zvernennia 7.05.21]. [in Ukrainian].

\title{
POSTGRADUATE SCHOOL IN UKRAINE AS THE BASIC FORM OF TRAINING SCIENTIFIC STAFF: CENTURY LONG REFLEXION
}

\author{
Oksana Petrenko \\ Doctor of Sciences (in Pedagogy), \\ Professor, Head at the Department of Theory and Methods of Education, \\ Rivne State University for the Humanities, \\ Rivne, Ukraine \\ ORCID: 0000-0001-6906-3542 \\ e-mail: oksana.petrenko@rshu.edu.ua
}

Liudmyla Balika

Candidate of Pedagogical Sciences, Associate Professor, Associate Professor at the Department of Theory and Methods of Education, Rivne State University for the Humanities,

Rivne, Ukraine

ORCID: 0000-0003-0042-7744 e-mail: luidmyla.balika@rshu.edu.ua

Svitlana Brychok

Candidate of Pedagogical Sciences, Associate Professor, Associate Professor at the Department of Primary Education Pedagogy, Rivne State University for the Humanities, Rivne, Ukraine ORCID: 0000-0001-8508-8395 e-mail: brychok.zd@gmail.com

\begin{abstract}
The article deals with a reflective analysis of the activities of postgraduate school in Ukraine as the main form of training the main form of training scientific staff for a century. It was found that nowadays postgraduate school in Ukraine by the Laws "On Education" (2017), "On Higher Education" (2014) is defined as the main form of training of scientific and pedagogical and scientific staff.

The contribution to the training of postgraduate students of research departments of pedology was investigated; postgraduate training programs at the department at the Kyiv Institute of Public Education have been analyzed. The activity of postgraduate study in pedagogy at the Ukrainian Research Institute of Pedagogy (URIP) in Kharkiv was characterized, the curricula and the basic principles of their functioning have been analyzed.

A number of normative documents that regulated the activities of postgraduate studies in Ukrainian educational institutions and the training of scientific and scientific-pedagogical staff in postgraduate studies were analyzed, among them: "Regulations on the Procedure for Training Scientists at Higher
\end{abstract}




\section{Інноватика у вихованні. Випуск 13.Том 2. 2021.}

Educational Institutions and Research Institutions" (1925), Resolution of the CEC of the USSR "On curricula and regimes in higher education and technical schools" (1932), Resolution "On the amount of scholarships for graduate students of universities, colleges and research institutes" (1933), Resolution "On the training of scientific and scientific-pedagogical workers" (1934), Law "On Measures to Improve the Training of Scientific and Pedagogical Staff in Postgraduate Studies" (1948), Resolution of the Higher Attestation Commission "On the results of work on the certification of scientific personnel in 1947/1948 academic year" (1948), Regulations on postgraduate studies at higher educational and research institutions (1962), Resolution of the Central Committee of the CPSU and the Council of Ministers of the USSR "On measures to improve the training and use of scientific, pedagogical and scientific staff (1987), About the statement of the Order of training applicants of higher education of a degree of the doctor of philosophy and the doctor of sciences in institutions of higher education (scientific institutions) (2016).

It is proved that in the 1930s the model of postgraduate studies in the USSR was "educational"; in the 50's of the $20^{\text {th }}$ century the development of postgraduate studies was reduced and transformed into a "research" model; at the beginning of the $21^{\text {st }}$ century postgraduate studies implement an educational and research model of training applicants.

Keywords: postgraduate study, scientific staff training, postgraduate student, doctor of philosophy, reflection.

Стаття надійшла до редакиіï 27.04.2021p. 